\title{
The Influence of the Religiosity Phenomenon on the Choice of Cars and Yogurt Brands
}

\section{Otomobil ve yoğurt markalarının seçiminde dindarlik fenomeni'nin etkisi}

\section{Selcuk Burak HASILOGLU 1*}

${ }^{1}$ Pamukkale University, Faculty of Economics and Administrative Sciences, Denizli. hasiloglu@pau.edu.tr 2 İstanbul Aydın University, The Graduate School (Institute) Of Social Sciences, İstanbul. emrecubukcuoglu@gmail.com * Corresponding author/ Yazışılan yazar

\begin{abstract}
Although there are numerous studies in which Christian religiosity has been associated with consumer behavior, there are few studies regarding the influence of Islam on marketing. However, religion has sustained its controlling and guiding effect on consumers in almost all societies throughout the ages. Accordingly, religion has a role in the decision-making process of the consumer, depending on the variety of the product. While this role is extremely dominant at times, it may be passive at other times. Accordingly, the variety of the product is an important factor in this relationship. In this study, the effect of religiosity on the preference of a car, as an example of a shopping product, and on a preference for yogurt brand, as an example of a convenience product, substantiated the relativity of the variety of the product. As a criterion of religiosity, the religiosity scale developed by Flere and Lavric (2008) as I+Ep and Es has been tested and adapted to this study. In the study model, the presence of a Islamic Attitude-integrated $\{I+E p\} \rightarrow$ Brand Loyalty positive relationship has been supported by SEM. As a result of this study, a significant relationship has been determined between extrinsic social (Es) religiosity and car brand choice. It can be concluded that this relationship is the result of conspicuous religiosity. Another remarkable result is that there is a significant relationship between yogurt brand and $\{I+E p\}$-type religiosity levels in the Turkish society. Conversely, it has been shown that there is no significant relationship between religiosity level for the $\{I+E p\}$ combination and car brand choice.
\end{abstract}

Keywords: Religiosity, Consumer Behavior, Convenience Products, Shopping Products, Islamic Attitude, Brand Loyalty, I+Ep and Es

JEL codes: $M 31$ doi: $10.5505 /$ pjess. 2016.10820

\section{Özet}

Bugüne kadar Hristiyan dindarlığının tüketici davranışı ile ilişiklendirildiği birçok çalışma olmasına rağmen Islamic marketing çalışmaları pek azdır. Oysaki hemen hemen her toplumda dinin tüketici üzerinde kontrol ve yönlendirici özelliğ $i$ asırlardan beri devam etmektedir. Dolayısıyla din olgusunun tüketicinin satınalma karar sürecinde, ürünün çeşitliliğine bağhl olarak bir rolü vardır. Bazen bu rol son derece baskın iken bazen de pasif olabilmektedir. Bu görecelikte ürünün çeşitliliği önemli bir faktördür. Bu çalışmada dindarlık olgusunun beğenmeli mal örneği olan araba (car) ve kolayda mal örneği olan yogurt markalarının tercihi üzerindeki etkisi araştırılmıştır. Dindarlık ölçüsü olarak Flere and Lavric (2008)'in I+Ep ve Es şeklinde ayırdiğg dindarlık ölçütünün araştırmanın modeline uyarlanmış hali test edilmiştir. Araştırmanın modelinde Islamic Attude $\rightarrow$ bütünleşik $\{I+E p\} \rightarrow$ Brand Loyalty pozitif yönlü ilişkisinin varlığı, SEM aracığı ile desteklenmiştir. Bu araştırma sonucunda extrinsic social (Es) religiosity düzeyi ile car brand choice arasında anlaml ilişkinin var olduğu tespit edilmiştir. Bu durumun gösterişçi dindarlıktan kaynaklandığııı söylemem mümkündür. Kayda değer bir diğer sonuç ise Müslüman Türk toplumu için kolayda mal statüsünde olan yoğurt markası tercihi ile $\{I+E p\}$ tipi dindarlı düzeyleri arasında anlamlı ilişkinin var olduğu yönündedir. Diğer yandan $\{I+E p\}$ kombinasyonuna ait religiosity düzeyi ile car brand choice arasında anlamlı ilişkinin olmadiğ kanıtlanmıştır.

Anahtar kelimeler: Dindarlık, Tüketici Davranışı, Kolayda Ürünler, Alışveriş Ürünleri, İslami Tutum, Marka Sadakati, I+Ep ve Es

JEL kodları: M31 


\section{INTRODUCTION}

The religiosity phenomenon is an important factor that has affected the life styles and behavior patterns of human beings for many centuries. It plays a significant role not only in the decisions people make but also in the decisions made by businesses, organizations and even countries. In fact, numerous wars and instances of discrimination have erupted because of differences in religious beliefs. Religion was used, to a great extent, as a means of oppression dating to the agrarian societies and lasting to the end of the Medieval Period. Even today, a directive and controlling nature of religion is extremely dominant in certain societies. On the one hand, this characteristic may improve, on an ethical level, the life styles and behaviors of society, but on the other hand, such control can be detrimental because it may give rise to the emergence of prejudice and misinformation. Moreover, controlling people by way of religious abuse is a severely unethical behavior.

The Turkish Republic is one of the states in which Islam is practiced and one that many other Muslim states can model. According to the life satisfaction survey conducted by the Turkish Statistical Institute (TURKSTAT), the proportion of those who state they are interested in religious subjects is $60.5 \%$, and that of those stating that they are indifferent to religion is $11 \%$. Today, the phenomenon of religiosity is used as a means of control under the name of the official state religion and ideology in societies such as those in the Far East and Africa, where people are forced to live as a colony without experiencing or living any religious reform. The great actors influencing the world economy, including China and India, also effectively exploit the religiosity phenomenon in their societies.

The influence of the religiosity phenomenon on consumers cannot be denied because it plays a role in the consumer purchasing decision process, depending on the variety of the product. This role is sometime extremely dominant, and at other times, it is quite passive. The variety of the product is an important factor in determining the influence of religion in the purchasing decision. In this study, the influence of the religiosity phenomenon on the choice of car brand, an example of a shopping product, and on the choice of yogurt brand, an example of a convenience product, is examined.

\section{THEORETICAL DEVELOPMENT}

Religion is a holy doctrine and plays an important role in human life. For this reason, many surveys have conducted on religiosity, that is, religious life style (Bergin, 1983). In these surveys, the religiosity factor has generally been considered an independent variable, and its influence on the projected dependent variable has been tested. One's level of religiosity influences many factors in his/her life. Consumer behavior is a factor that is influenced by the phenomenon of religiosity.

Many studies have been conducted regarding the influence of the religiosity factor on business and consumer ethics. These studies can be classified under the headings of religiosity and morality because they measure religiosity, the impact of religiosity on moral philosophies and moral intensity, the impact of religiosity on ethical judgments, and behavior (Vitell, 2010). Though many studies correlate Christian religiosity with marketing science, only a few studies have been conducted with respect to Islam and marketing. However, the book edited by Sandikci and Rice (2011) is so informative that it compensates 
for many deficiencies in this field. The number of Islamic marketing studies in Turkey, where the majority of the population is Muslim, is very limited. Sandikci and Ger (2010), who examined the fashion of modest dress in an ethnographic survey conducted in Turkey, observed a symbiotic relation between marketing and Islam. Odabasi and Argan (2009) examined consumer patterns during Ramadan, which is the Muslims' sacred month. Muhamad and Mizerski (2013) test the role of consumers' intrinsic and extrinsic Islamic religiosity in their decision making regarding the consumption about taboo products.

According to Kurt Lewin's black box model, numerous stimuli affect consumer behaviors either positively or negatively. Generally, the consumer behavior factors are divided into five groups: situational, psychological, personal, cultural and social. The religiosity phenomenon has a great impact on most of these factors and on the black box model (İzberk-Bilgin, 2012; Patwardhan et al., 2012; Swimberghe, Sharma and Flurry, 2011; Essoo and Dibb, 2004).

Accordingly, we need a religiosity scale to test the influence of the level of religiosity on other factors in human life. In the first studies related to measuring the religiosity level, the frequency of attending prayer events was considered a criterion, but it was not considered sufficient (Karaşahin, 2008:194) because not only behaviors but also many other factors, such as attitude, influence the measurement of religiosity, a concept that consists of several dimensions. Smart's study (1982) is one of the examples revealing that religion consists of different dimensions.

Generally, religiosity, which is also a pathfinder in the measurement of religiosity, is divided into five dimensions. The first is the dimension of belief. In this dimension, the religious person accepts the doctrines of his/her religion. These doctrines may vary among subgroups within the same religion. Second is the dimension of religious practice, which includes rituals and devotions. Another dimension is that of experience, which is related to religious practice, beliefs and implementation, but it is more sensitive and more private. The fourth dimension is that of knowledge. In this dimension, the individual knows the rules of the religion with respect to ethics, beliefs and prayer events. The last is the dimension of consequences, which suggests that the individual should engage in the four previous dimensions (Stark and Glock, 1978: 256-258; Kayıklık, 2006: 493).

Conversely, there are various attitudes regarding one's lifestyle as a human being that are impacted or controlled by religion. For this reason, lifestyle and attitudes that are the results of one's religion can be effective in measuring religiosity. For instance, Muslims try to live according to the sunnah and to the advice and commands in their sacred book (Şeker, 2011:191). Simplicity, thrift, frugality, altruism, humanism, philanthropy and traditionalism are all characteristics of the Islamic attitude. Actually, these attitudes exist not only in Islam, but in nearly all religions. In this study, the attitudes that are important and privileged among Muslims are considered Islamic attitudes. The Islamic attitudes examined in this study are simplicity (Quran: Bakara 264, Nisa 38, Enfal 47, Maun 6; Hadith: Aclûnî, Keşf ElHafa, Tirmizî, Libas), thrift (Quran: Nisa 6, En'am 141, A'raf 31, Furkan 67; Hadith: Buhari, Bezzar, Et'ime, Tirmizi) and traditionalism.

Considered a reference in many studies related to religiosity measurement, Allport and Ross (1967) assert that religiosity should be measured in a bipolar form as extrinsic orientation and intrinsic orientation and, accordingly, called the Religious Orientation Scale. The 
extrinsic orientation subscale measures one's tendency to use religion as his interest. Those who have this feature allow their religion to fulfil their social needs. The intrinsic orientation subscale measures the tendencies completely motivated by one's religious beliefs. People with this feature endeavor to experience and internalize their beliefs (Allport and Ross, 1967: 434). Thus, the extrinsic subscale measures those who exploit religion, while the intrinsic subscale measures those who experience religion. Accordingly, both also measure the ethical depth of the individual.

Gorsuch and McPherson (1989) divide the extrinsic subscale into two parts: extrinsic social orientation (Es) and extrinsic personal orientation (Ep). Socially extrinsic orientation suggests that the individual uses religion as a means to achieve social advantage. Personally extrinsic orientation suggests that religion serves as a means of protection, offering peace and happiness. Providing peace, relaxation and happiness is the foundation of this form of religious motivation. Personally extrinsic religiosity is related with to personal satisfaction, such as feelings of peace brought about by praying (Gorsuch and Mcpherson, 1989: 353).

The differentiation and combination of intrinsic (I), Ep and Es orientations can vary from one religious group to another. Flere and Lavric's study (2008) on Bosnian Muslims, Serbian Orthodox, Slovenian Catholics and US Protestants is about the differentiation and combination of these three factors. According to this study, intrinsic orientation and extrinsic personal orientation are in unity (I+Ep) in all groups other than among US Protestants. Namely, I and Ep exist in a single factor according to Bosnian Muslims, while the Es factor is a separate factor (Flere and Lavric, 2008:526).

In accordance with the data from the literature, the model of the survey is presented in Figure 1. There is a relationship between Islamic attitude classified as simplicity, thrift and traditionalism and both Es and I+Ep (combination of intrinsic and extrinsic personal orientation), according to the specified model. There is also a relationship between both Es and I+Ep and brand loyalty. In this model, the brand loyalty factor has been examined separately for automotive brands and yogurt brands.

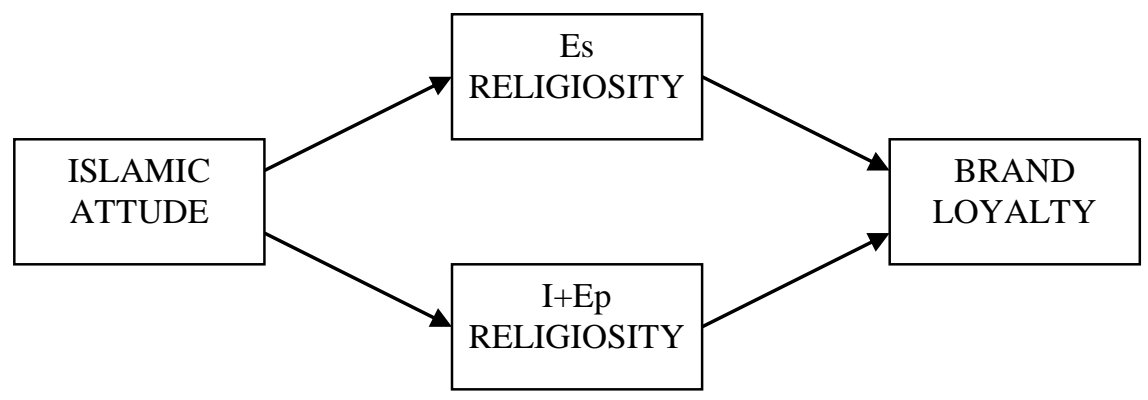

Figure 1. The model based on theoretical structure

As presented in Figure 1, the religiosity factors of the survey model are divided into two groups: Es and I+Ep. This differentiation is determined by using Flere and Lavric's study (2008), which was inspired from the work of Gorsuch and McPherson (1989), as a reference. 
Discrimination continues to be a worldwide problem including in the developed countries. Race and religion are two of the most important factors driving discrimination (Nosek et al., 2006; Landrine and Klonoff, 1996), and prejudice is considered the most important reason for discrimination. For instance, most of the religious groups teach their members that people who are not members of their own group are condemned to unpleasant situations after death and that members should avoid any relationships with non-members (Cirhinlioğlu, 2010). Conversely, according to Choi et al. (2010), people whose religiosity levels are high are more likely to use the members of their own religious group as a product information source than are those whose religiosity levels are low.

In the studies, it is determined that people whose religiosity levels are higher have higher levels of prejudice (Cirhinlioğlu, 2010: 1369). These data indicate that one's religiosity level effectively influences the consumer purchase decision process. A consumer with a high level of religiosity is thus more likely to act upon his/her prejudices. Similarly, the influence of prejudice on brand loyalty started to be accepted in 1970s (Jacoby and Chestnut, 1978:80).

Allport determined that churchgoers' level of racial prejudice was higher than that of nonchurchgoers in the 1950s (Allport and Ross, 1967), while Billiet (1995) put forth that religiosity had a positive impact on racial attitudes.

In this context, apart from testing the convenience of the model, this study aims to test the three hypotheses and search for answers to their related questions. Accordingly, the first hypothesis is related to the preferred brand of cars because cars are considered a symbol of social class. As in almost all societies, social class plays a part in the car purchasing decision process and in the brand choice for Turkish consumers (Uğurlu, 2009: 1459). Moreover, car brand is not only a symbol of social status but also a factor in conspicuous consumption (Yoon, 1996). The car is one of the products classified as a shopping product. With respect to shopping products, their purchase frequency is rare, there is a need for high-level contact between the producer and the consumer, and the purchasing decision process is slow. Because the individual's social level or expectation is high with respect to extrinsic social religiosity, whether there is a relationship between the individual's extrinsic social religiosity and his/her choice of car brands must be determined, and if so, the reasons for this relationship should be examined.

$\mathrm{H}_{\mathrm{A}}$ : There is a significant difference in extrinsic social religiosity with respect to the car brand choice.

Cars are in the shopping products group, and yogurt is in the convenience products group in Turkish society. Convenience products are fast moving consumer goods that meet basic needs and are readily available. Yogurt is a cultural food in the Turkish society. It can be produced at home or quickly and easily purchased from any grocer. According to research of Turkish Statistical Institute, yogurt is a nutritional source that is consumed even more than milk. It is found on almost every dining table in the company of all types of meals. In short, yogurt is a product that addresses a basic need of Turkish consumers. In this context, this study aims to determine whether there is a relationship between an individual's religiosity level $(\mathrm{Ep}+\mathrm{I})$ and his/her choice of yogurt brands, and if so, the reasons behind this relationship. Using the same approach, the study aims to determine whether there is a relationship between religiosity $(\mathrm{Ep}+\mathrm{I})$ and car brand. 
$\mathrm{H}_{\mathrm{B}}$ : There is a significant difference in religiosity $(\mathrm{Ep}+\mathrm{I})$ with respect to yogurt brand choice.

Hc: There is a significant difference in religiosity $(\mathrm{Ep}+\mathrm{I})$ with respect to car brand choice.

\section{METHOD}

Structural equation modelling (SEM) was used to test the research model. Initially, confirmatory factor analysis was conducted to determine content validity and reliability, which are factors in the model. Then, correlation analysis was conducted to examine the relationship between the variables. The hypotheses of the research were tested using the Chisquare test. The Lisrel package was used in the structural equation model, and the SPSS package was used in other statistical analyses such as the Chi-square and correlation analyses.

Gorsuch and McPherson's (1989:353) I/E-R scale, which was revised from Allport and Ross' (1967) Religious Orientation Scale, was incorporated as a religiosity scale in the model. The quotation, "My religion is important because it answers many questions about the meaning of life", which does not exist on the I/E-R scale but does exist on the Religious Orientation Scale and The Religious Commitment Inventory - 10 Scale developed by Worthington et al. (2003: 87) was added as an item to the religiosity scale of our study.

Some scale items that are considered universal in the marketing literature are appropriate for measuring the brand loyalty levels of respondents. For example, "I will prefer the brand that I use if I go shopping today", "I will buy the same brand even if its price increases" and "I am an advocate of the brand that I use" (Tucker, 1964; Jacoby and Kyner, 1973; Chaudhuri, 1999; Rundle-Thiele and Mackay, 2001; Sirdeshmukh et al., 2002).

Finally, the questions presented on the questionnaire that aimed to learn the yogurt and car brands that respondents prefer were asked to find answers to the hypotheses being tested and, correspondingly, to the survey questions.

\subsection{Sample and Data Collection}

The population sample includes the people living in the city of Denizli, which is located in the Aegean region of Turkey. The findings of our survey are sufficient to mirror the general situation of Turkey because the internal migration from different regions of the country to this city has recently increased. According to the Turkey's 2009 National Population Census data, there are 78 neighborhoods in the city, and there are 498360 inhabitants. When each neighborhood was analyzed as an item according to age groups, the average correlation coefficient was found to be 0.901 , and the alpha coefficient was 0.986 , which indicated that the homogeneity was high among neighborhoods. Therefore, cluster sampling method was used as the sampling method. It was considered appropriate that data would be collected from ten neighborhoods randomly, and the sample size was calculated as $246(\mathrm{~N}=498360$, $\mathrm{Z}=1.96(95 \%), \mathrm{P}=0.8$ and $\mathrm{E}=0.05)$.

The survey data were collected by a team of ten people in face-to-face interviews. The pollster team reached the subjects in ten chosen neighborhoods by systematic sampling with respect to residential order. They acted under the principle that if there was nobody at home, if the subjects refused to answer or if there was misinformation, then they interviewed the next home. The summary data of the sample are shown in Table 1. 
Table 1. Sample characteristics

\begin{tabular}{|c|c|}
\hline $\begin{array}{c}\text { Descriptor } \\
(\mathrm{n}=246)\end{array}$ & Freq. (Percent) \\
\hline \multicolumn{2}{|l|}{ Gender } \\
\hline Female & $105(42.68 \%)$ \\
\hline Male & $141(53.32 \%)$ \\
\hline \multicolumn{2}{|l|}{ Age } \\
\hline Under 21 & $36(14.63 \%)$ \\
\hline $21-25$ & $55(22.36 \%)$ \\
\hline $26-30$ & $53(21.54 \%)$ \\
\hline $31-40$ & $58(23.58 \%)$ \\
\hline Over 40 & $44(17.89 \%)$ \\
\hline \multicolumn{2}{|l|}{ Income/year (EURO) } \\
\hline Under 5000 & $46(18.7 \%)$ \\
\hline$[5000-7500)$ & $66(26.83 \%)$ \\
\hline$[7500-10000)$ & $43(17.48 \%)$ \\
\hline$[10000-15000)$ & $47(19.11 \%)$ \\
\hline Over 15000 & $44(17.89 \%)$ \\
\hline \multicolumn{2}{|l|}{ Education } \\
\hline Less than high school & $60(24.39 \%)$ \\
\hline High school & $95(38.62 \%)$ \\
\hline University & $91(36.99 \%)$ \\
\hline \multicolumn{2}{|l|}{ Occupation } \\
\hline Worker & $74(30.08 \%)$ \\
\hline SMEs Manager & $31(12.6 \%)$ \\
\hline Professional & $32(13.13 \%)$ \\
\hline Official & $17(6.91 \%)$ \\
\hline Teacher & $12(4.88 \%)$ \\
\hline Student & $45(18.29 \%)$ \\
\hline Housewife & $27(10.98 \%)$ \\
\hline Retiree & $14(5.69 \%)$ \\
\hline Unemployed & $6(2.44 \%)$ \\
\hline \multicolumn{2}{|c|}{ The number of employees in the family } \\
\hline 0 & $13(5.28 \%)$ \\
\hline 1 & $106(43.09 \%)$ \\
\hline 2 & $96(39.02 \%)$ \\
\hline 3 & $28(11.38 \%)$ \\
\hline 4 & $3(1.22 \%)$ \\
\hline
\end{tabular}

\subsection{The Results of the Structural Model}

The factors and items in the model were evaluated by applying confirmatory factor analysis (CFA). The results indicated that Es religiosity factor and some items in the I+Ep factor were inappropriate for this model. (RMSEA $>0.1 ; \chi^{2} / \mathrm{df}>4 ; \mathrm{NFI}, \mathrm{NNFI}, \mathrm{CFI}, \mathrm{IFI}, \mathrm{GFI}$ and AGFI were less than 0.75 ). The finding that the model including the Es religiosity factor was not suitable for representing the survey population (Muslim Turkish people) was not an unexpected result. An individual with socially extrinsic orientations was found to be weaker ethically because he/she has a tendency toward false pretense. The impropriety of prayer for the purpose of exhibition is clearly elucidated in the sacred book of the Muslim, the Quran (Quran: Maun 4-7). Accordingly, this religious community does not disapprove of false pretense either ethically or religiously. In addition to the Es religiosity factor, the reversed items in the I+Ep factor such as "It does not much matter what I believe as long as I am 
good", "Although I am religious, I do not let it affect my daily life" and "Although I believe in my religion, many other things are more important in life" were excluded from the model. It was understood that the cause of confusion in the respondent's mind was that such items were asked in the reverse to measure the intrinsic religiosity level. The appropriate models (Figure 2) and factors (Figure 3), as revised in line with these data, are reorganized and presented in the following figures. The finding regarding the convenience of the I and Ep religiosity combination in the model also supports the work of Flere and Lavric (2008).

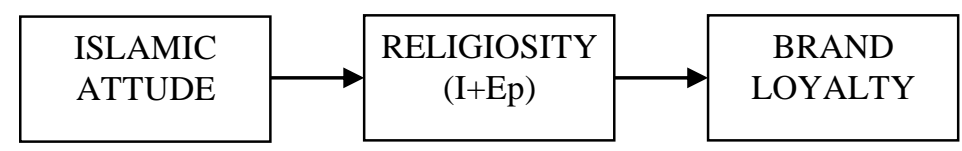

Figure 2. Revised model

As a consequence of the analysis, it was determined that the measuring model was appropriate, and the values for goodness of fit were examined before developing the model that would be established using the structural equation modelling $\left(\chi^{2}=110.74, \mathrm{df}=51\right.$, $\chi^{2} / \mathrm{df}=2.17, \mathrm{RMSEA}=0.069, \mathrm{SRMR}=0.053, \mathrm{NFI}=0.89, \mathrm{NNFI}=0.91, \mathrm{CFI}=0.93, \mathrm{IFI}=0.93, \mathrm{GFI}=0.93$, AGFI $=0.89$ and Cronbach's alpha $=0.88$ ). The factors of the ultimate model giving the best fit are presented in Figure 3. As evidenced in Figure 3, the Islamic attitude (ISAT) factor consists of 3 items, the I+Ep religiosity (IEpR) factor consists of 6 items and the brand loyalty (BLOY) factor consists of 3 items. The order of loads of items explaining these three factors according to importance is again presented in Figure 3. In other words, these items explain the variance in their related latent variables. There is no relationship between Islamic attitude and brand loyalty among the latent variables.

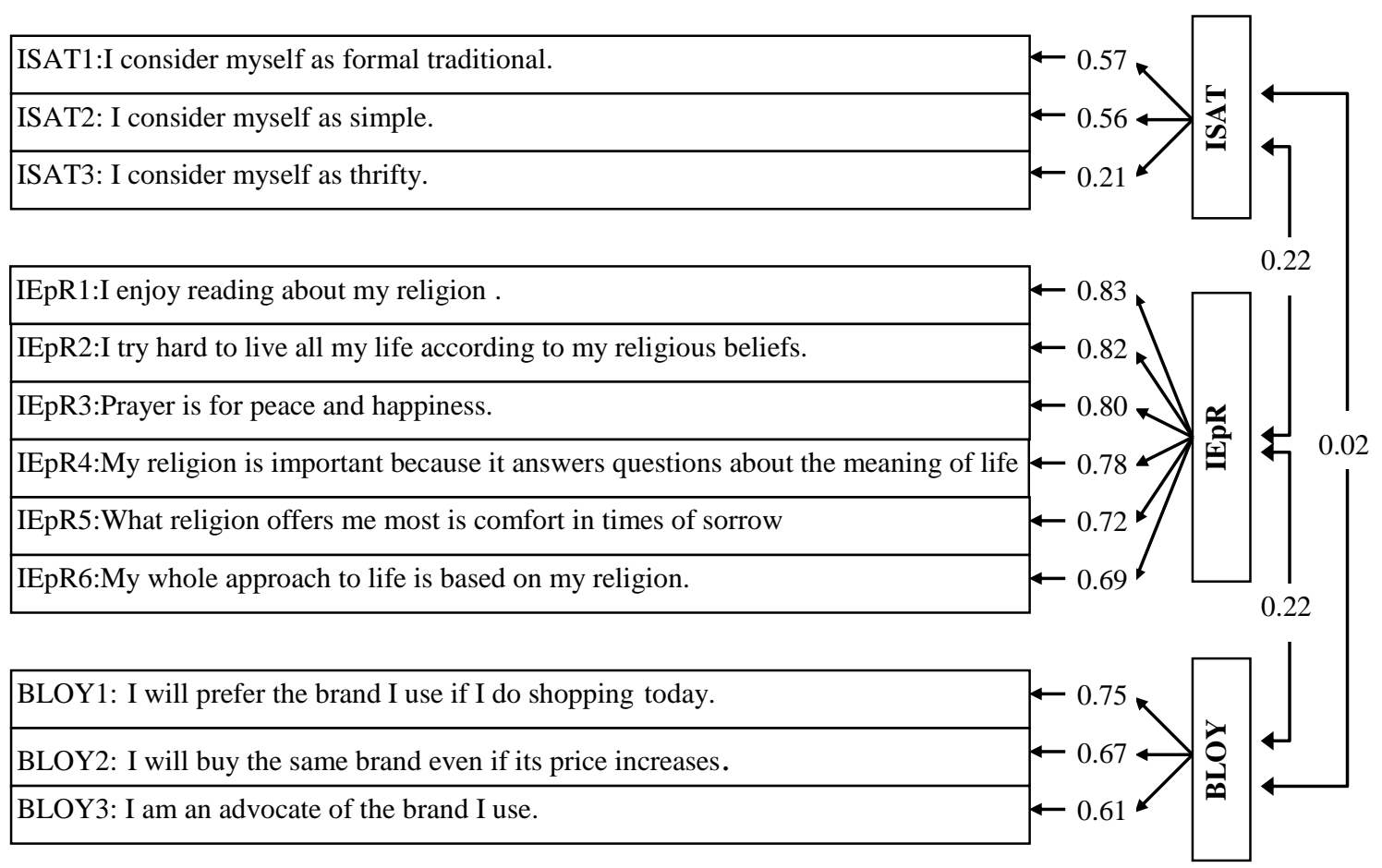

Figure 3. Factor measurement model

(Note: All standardized loading solutions are significant at the 0.05 level.) 
The table of correlation between model factors and demographic data is displayed in Table 2 . As evidenced in the table, the religiosity (I+Ep) level of respondents decreases as their educational level increases. A similar situation is true for the income state and the number of employees in the family. There is an inversely proportional relationship between these variables and religiosity level. That is, the religiosity level decreases as the income state or the number of employees in the family increases. In addition, the data in the table indicate that there is a meaningful and positive relationship between religiosity level and customer loyalty.

Table 2. Intercorrelations of factors and sample characteristics

\begin{tabular}{|c|c|c|c|c|c|c|c|}
\hline $\begin{array}{l}\text { Variables } \\
(\mathrm{n}=246)\end{array}$ & 1 & 2 & 3 & 4 & 5 & 6 & 7 \\
\hline 1. AGE & - & & & & & & \\
\hline 2. EDUCATION & $-0.300 * *$ & - & & & & & \\
\hline 3. INCOME & 0.018 & $0.345 * *$ & - & & & & \\
\hline 4. EMP.NUM. & $-0.284 * *$ & $0.277 * *$ & $0.418 * *$ & - & & & \\
\hline 5. REL.FACTOR & 0.065 & $-0.220 * *$ & $-0.184 * *$ & $-0.181 * *$ & - & & \\
\hline 6. ATT.FACTOR & $0.126^{*}$ & -0.030 & 0.006 & -0.065 & 0.123 & - & \\
\hline 7. LOY.FACTOR & 0.038 & 0.023 & 0.055 & -0.061 & $0.158^{*}$ & -0.022 & - \\
\hline
\end{tabular}

Notes:

1. ${ }^{*}$ Correlation is significant at the 0.01 level (2-tailed)

** Correlation is significant at the 0.05 level (2-tailed).

2. EDUCATION, education level (1=least); EMP.NUM., the number of employees in the family; REL.FACTOR, Religiosity (I+Ep) factor; ATT.FACTOR, Attitude factor; LOY.FACTOR, Loyalty factor.

After the confirmatory factor analysis, the decision model suggested in the study was tested using structural equation modelling to determine the relationships among the latent variables in the model. It was found that the relationships are meaningful when all of the $t$ values used to test the model and the standardized solution values are confirmed (Figure 4).

When the model's goodness of fit statistical values were verified, the RMSEA $=0.068$, $\mathrm{SRMR}=0.053, \mathrm{NFI}=0.89, \mathrm{NNFI}=0.91, \mathrm{CFI}=0.93, \mathrm{IFI}=0.93, \mathrm{GFI}=0.93, \mathrm{AGFI}=0.89$ and $\chi^{2} / \mathrm{df}=2.25$ $\left(\chi^{2}=110.75, \mathrm{df}=52\right)$. The values for goodness of fit resulting from the analysis indicate that the revised model of the study is acceptable. In other words, the existence of meaningful paths from Islamic attitude to the religiosity factor consisting of I and Ep and from the religiosity factor to brand loyalty is not rejected. 


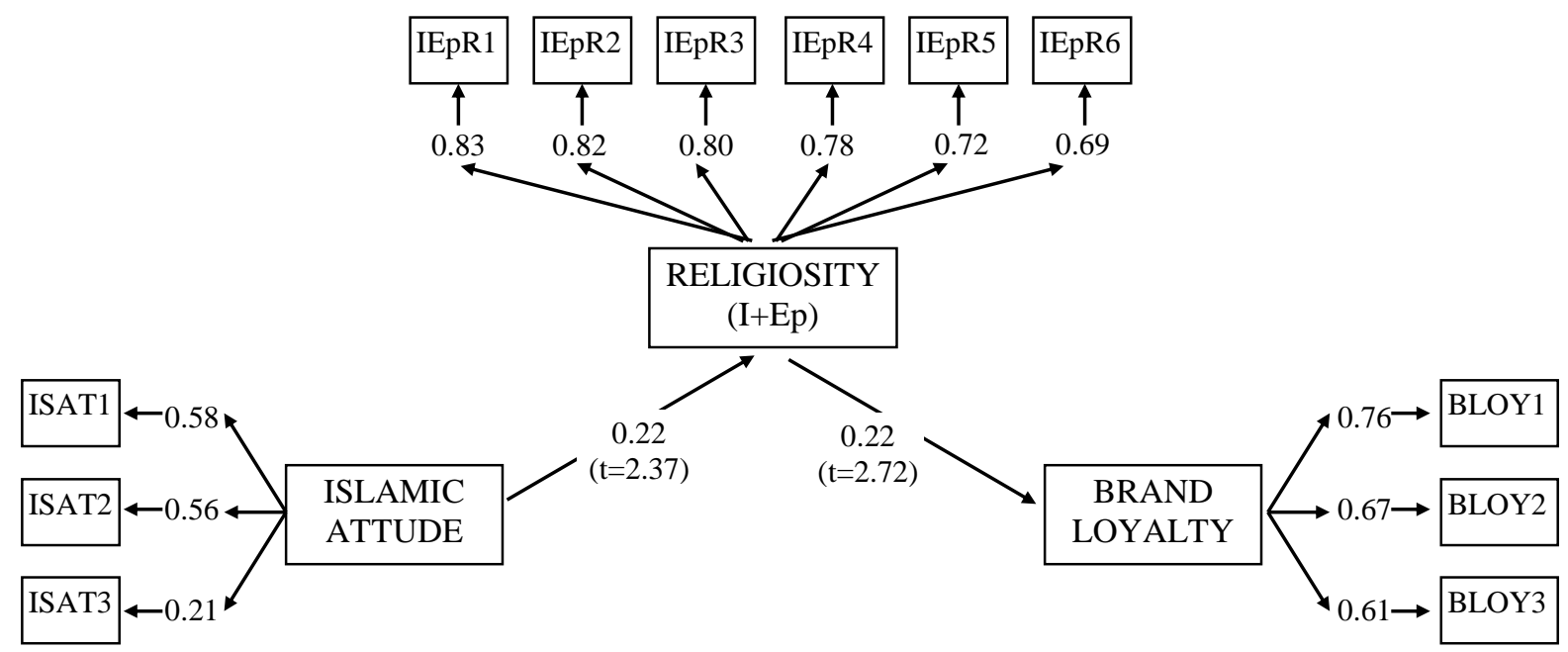

Figure 4. Structural model

(Note: All standardized loading solutions are significant at the 0.05 level.)

\subsection{Hypotheses Tests}

The Chi-square and SEM path analyses were used to test the hypotheses. Hypothesis A of the study considers the relationship between extrinsic social religiosity and car brand preference. For this purpose, the cross-table data in Table 3 were tested using the Chi-square analysis, and it was found that the asymptotic significance was at the proper level $(p<0.05)$. Hence, $\mathrm{H}_{\mathrm{A}}$ was accepted. As presented in the table, Mercedes, Toyota, Volkswagen and Volvo become the more preferred brands as the Es religiosity level increases. These brands are the most expensive among their segments. In other words, a preference for the more expensive car brands among their segments increases as the Es religiosity level increases.

Table 3. Cross-tabulation of Es religiosity and car brands

\begin{tabular}{|c|c|c|c|c|c|c|c|c|c|c|}
\hline Brands & & Fiat & Ford & Mercedes & Opel & Peugeot & Renault & Toyota & VW & Volvo \\
\hline \multirow{5}{*}{ 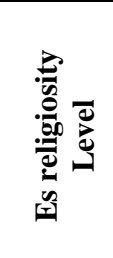 } & 1 & $10.0 \%$ & $21.7 \%$ & $8.9 \%$ & $3.6 \%$ & $8.7 \%$ & $4.3 \%$ & $7.7 \%$ & $2.6 \%$ & $5,3 \%$ \\
\hline & 2 & $30.0 \%$ & $13.0 \%$ & $16.1 \%$ & $39.3 \%$ & $43.5 \%$ & $47.8 \%$ & $26.9 \%$ & $13.2 \%$ & $26,3 \%$ \\
\hline & 3 & $20.0 \%$ & $17.4 \%$ & $17.9 \%$ & $14.3 \%$ & $21.7 \%$ & $13.0 \%$ & & $5.3 \%$ & $5,3 \%$ \\
\hline & 4 & $10.0 \%$ & $17.4 \%$ & $33.9 \%$ & $10.7 \%$ & $4.3 \%$ & $17.4 \%$ & $19.2 \%$ & $26.3 \%$ & $21,1 \%$ \\
\hline & 5 & $30.0 \%$ & $30.4 \%$ & $23.2 \%$ & $32.1 \%$ & $21.7 \%$ & $17.4 \%$ & $46.2 \%$ & $52.6 \%$ & $42,1 \%$ \\
\hline Total & & $100,0 \%$ & $100.0 \%$ & $100.0 \%$ & $100.0 \%$ & $100.0 \%$ & $100.0 \%$ & $100.0 \%$ & $100.0 \%$ & $100.0 \%$ \\
\hline
\end{tabular}

$\chi^{2}=53.749 ; \mathrm{df}=32 ; \mathrm{p}=0.009$ (2-sided)

Hypothesis B considers the relationship between religiosity (Ep+I) and yogurt brand preference. For this purpose, the cross-table data in Table 4 were tested using a Pearson Chisquare analysis, and it was found that the asymptotic significance was at the proper level $(\mathrm{p}<0.05)$. Hence, Нв was accepted. As presented in the table, the level of preference for the Ülker yogurt brand is extremely significant as the I+Ep religiosity level increases. The most preferred yogurt brand for those at a low I+Ep religiosity level is Sütaş. 
Table 4. Cross-tabulation of I+Ep religiosity and yogurt brands

\begin{tabular}{|c|c|c|c|c|c|c|c|c|c|}
\hline \multicolumn{2}{|c|}{ Brands } & Danone & Pınar & Sakıpağa & SEK & Sütaş & Tikveşli & Ülker & Yörsan \\
\hline \multirow{5}{*}{ 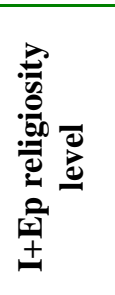 } & 1 & & $4.8 \%$ & & & $6.2 \%$ & & & \\
\hline & 2 & $11.1 \%$ & $6.5 \%$ & $11.1 \%$ & $6.7 \%$ & $7.7 \%$ & $23.8 \%$ & $3.0 \%$ & $17,4 \%$ \\
\hline & 3 & $22.2 \%$ & $25.8 \%$ & & & $29.2 \%$ & $14.3 \%$ & $9.1 \%$ & $17,4 \%$ \\
\hline & 4 & $55.6 \%$ & $38.7 \%$ & $55.6 \%$ & $46.7 \%$ & $38.5 \%$ & $42.9 \%$ & $24.2 \%$ & $26,1 \%$ \\
\hline & 5 & $11.1 \%$ & $24.2 \%$ & $33.3 \%$ & $46.7 \%$ & $18.5 \%$ & $19.0 \%$ & $63.6 \%$ & $39,1 \%$ \\
\hline Total & & $100,0 \%$ & $100.0 \%$ & $100.0 \%$ & $100.0 \%$ & $100.0 \%$ & $100.0 \%$ & $100.0 \%$ & $100.0 \%$ \\
\hline
\end{tabular}

The positive relationship between the Ülker brand and I+Ep religiosity was also supported by SEM (structural equation modelling). For this purpose, the data showing a preference for Ülker were included with the I+Ep religiosity factor in the structural model of the study as an additional article. Accordingly, path values between them were $\beta=0.43$ and $\mathrm{t}=6.80\left(\chi^{2}=133.76\right.$, $\mathrm{df}=63, \chi^{2} / \mathrm{df}=2.12, \mathrm{RMSEA}=0.068, \mathrm{SRMR}=0.054 ， \mathrm{NFI}=0.88, \mathrm{NNFI}=0.91 ， \mathrm{CFI}=0.93 ， \mathrm{IFI}=0.93$, $\mathrm{GFI}=0.92$, AGFI=0.89). Similarly, the reverse relationship between the Sütaş brand and I+Ep religiosity was also supported by SEM. The data showing a preference for Sütaş with I+Ep religiosity factor were included as an additional article. Accordingly, the path values between them were $\beta=-0.19$ ve $t=-2.88 \quad\left(\chi^{2}=145.02, \quad \mathrm{df}=63, \chi^{2} / \mathrm{df}=2.30, \quad \mathrm{RMSEA}=0.073\right.$, $\mathrm{SRMR}=0.059, \mathrm{NFI}=0.88, \mathrm{NNFI}=0.88, \mathrm{CFI}=0.91, \mathrm{IFI}=0.91, \mathrm{GFI}=0.92, \mathrm{AGFI}=0.89$ ).

Hypothesis $\mathrm{C}$ considers the relationship between religiosity $(\mathrm{Ep}+\mathrm{I})$ and car brand preference. This hypothesis was tested using a Chi-square analysis, and it was found that the asymptotic significance was not at the proper level $(\mathrm{p}=0.409)$. Hence, Hc was rejected.

\section{DISCUSSION AND RESULTS}

Religion has an important influence on societies, and the religiosity phenomenon is one of the most important factors in the cultures of all societies. At the same time, the importance of consumers has increased with the changing marketing environment. For this reason, businesses must consider the factors that influence consumer behavior when determining their marketing strategies. As is well known, consumers demand not only maximum advantage economically but also the most appropriate brands that define them both socially and culturally when making purchasing decisions. The psychological and personal traits of consumers can also influence the purchasing decision. Intertwining, to some degree, with most of these factors, the influence of the religiosity phenomenon on consumer behavior is at a remarkably high level. Within this survey, the stimulant role of Islamic religiosity in the black box model has been evaluated within the frame of the determined theoretical structure.

In this study, Flere and Lavric's religiosity scale (2008) (classified as I+Ep and Es) was adapted to the survey model and tested. The positive relationship of Islamic Attitude $\rightarrow$ integrated $\{\mathrm{I}+\mathrm{Ep}\} \rightarrow$ Brand Loyalty in the model was supported by SEM. While simplicity and thrift are extremely important in Islam, as in many religions, the Islamic attitude also emphasizes traditionalism. Moreover, this subject is repeated in many parts of the Quran. These two items are so important that wastage is forbidden and those trying to 
make false pretense are disapproved of. Again, religious Muslims make it their duty to follow their prophet's actions (sunnah) and consider hadiths to be a course of action in their lives. The information about sunnah and hadiths has been passed down through the generations and survives today. Hence, one of the indications of Islamic religiosity is traditionalism. Some items of Allport and Ross's (1967) Religious Orientation Scale, however, have been excluded from the model because they decrease the internal consistency and fit values of the SEM. The general trait of these scale items is the reverse items, such as "It does not much matter what I believe so long as I am good", "Although I am religious, I do not let it affect my daily life" and "Although I believe in my religion, many other things are more important in life". The respondents may have had difficulty distinguishing such items. Briefly, a positive relationship was determined between the integrity of intrinsic and personally extrinsic religiosity, as supported by Islamic attitude and brand loyalty.

Conversely, the model for the relationship between Islamic Attitude $\rightarrow$ Es $\rightarrow$ Brand Loyalty was rejected by our survey findings. The conflict arose from the fact that Es, as socially extrinsic religiosity, was based on exhibition, while the Islamic attitude of each path, as established by Es, included simplicity and thrift. Moreover, the impropriety of prayer for the purpose of exhibition is clearly emphasized in the Quran. This finding also shows that measuring socially extrinsic religiosity attitude in Muslims is difficult when using the scale items in the literature (Allport and Ross, 1967; Gorsuch and Mcpherson, 1989). For these reasons, the study found that the path between the Islamic attitude and Es and the path between brand loyalty and Es are incompatible. Hence, the combination of I+Ep is an acceptable religiosity scale for Muslims, while Es is indicative of conspicuous religiosity.

Another conclusion provided by this study is that the religiosity (I+Ep) level has an inversely proportional relationship with education and level of income. Namely, internal religiosity decreases as the level of education or income increases. Conversely, internal religiosity increases as the level of education or income decreases. This finding has been proven in many studies conducted on religiosity.

The three hypotheses were tested within the scope of the survey, and it was found that a meaningful relationship exists between extrinsic social religiosity level and car brand choice according to the first hypothesis. Cars are a symbol of social class. Moreover, because cars are the production of conspicuous consumption, it was determined that this trait was influential on the choice of car brands made by religious people with a high level of extrinsic social religiosity. As the Es religiosity level increased, Mercedes, Toyota, Volkswagen and Volvo became the more preferred brands. That is, the choice for the more expensive cars among their segments increased as the Es religiosity level increased. Another inference made from this hypothesis is that religious people with a high level of extrinsic social religiosity gravitate to conspicuous consumption in their choices of shopping products.

According to the test of the second hypothesis, a meaningful relationship was found between religiosity levels and the choice of yogurt brand, which represents a convenience product for Turkish Muslims. The preference for the Ülker yogurt brand increases as the religiosity level increases, while the preference for the Sütaş yogurt brand increases as the religiosity level decreases. The Ülker brand has prioritized the images of Muslimism and Turkism in their marketing activities for many years, and it has embedded images of religiosity and 
ethnocentrism in the subconscious mind of the consumer through advertising campaigns and sponsor choices. Hence, the Ülker brand has become a product that is primarily preferred by consumers with a high level of religiosity. Nevertheless, the fact that the company bought a global brand, Godiva, and entered into international marketing caused a step-by-step change in their marketing strategy. Ülker's recent marketing activities that have eliminated the dominant religious image have appeared in national newspapers and social media. Although the company has continued the image changing campaign, this survey determined that it was the privileged brand for consumers with a high level of religiosity and that these consumers demonstrate brand loyalty. Conversely, the news in the press and social media about the company has caused a decrease in the preference for the Sütas brand as the religiosity level increases. According to the rampant spread of this news on the Internet, the Sütaş Company forbade employees to pray during working hours, but the company later abolished this policy.

Though religiosity is influential with respect to convenience products, the same cannot be said for shopping products. This premise was proven by the rejection of our third hypothesis. That is, it was demonstrated that there was no meaningful relationship between the religiosity level of the I+Ep combination and car brand choice.

In conclusion, while religiosity is an important factor that can be exploited by the convenience product businesses in marketing, it is not as influential in the shopping product businesses. Conversely, because cars, as an example of a shopping product, are a symbol of social class, such products are important for consumers with a high level of socially extrinsic and conspicuous religiosity.

\section{REFERENCES}

Allport, G. W., \& Ross, J. M. (1967). Personal Religious Orientation and Prejudice. Journal of Personality and Social Psychology, 5(4), 432 - 443.

Bergin, A. E. (1983). Religiosity and Mental Health: A Critical Reevaluation and MetaAnalysis. AMCAP Journal, 9(3), 5-22.

Billiet, J.B. (1995). Church Involvement, Individualism, and Ethnic Prejudice among Flemish Roman Catholics: New Evidence of a Moderating Effect. Journal for the Scientific Study of Religion, 34(2), 224-233.

Chaudhuri, A. (1999). The Relationship of Brand Attitudes and Brand Performance: The Role of Brand Loyalty. The Journal of Marketing Management, 9(3), 1-9.

Choi, Y. Kale, R., \& Shin, J. (2010). Religiosity and Consumers' Use of Product Information Source among Korean Consumers: An Exploratory Research. International Journal of Consumer Studies, 34, 61-68.

Cirhinlioğlu, F. G. (2010). Dini Yönelimler ve Önyargi. Uluslararası İnsan Bilimleri Dergisi, 7(1), 1366-1384. 
Essoo, N., \& Dibb, S. (2004). Religious Influences on Shopping Behaviour: An Exploratory Study. Journal of Marketing Management, 20, 683-712.

Flere, S., \& Lavric, M. (2008). Is Intrinsic Religious Orientation A Culturally Specific American Protestant Concept? The Fusion of Intrinsic and Extrinsic Religious Orientation among Non-Protestants. European Journal of Social Psychology, 38(3), 521530.

Gorsuch, R. L., \& Mcpherson, S. E. (1989). Intrinsic/Extrinsic Measurement: I/E-Revised and Single-Item Scales. Journal for the Scientific Study of Religion, 28(3), 348-354.

Izberk, Bilgin E. (2012). Infidel Brands: Unveiling Alternative Meanings of Global Brands at the Nexus of Globalization, Consumer Culture, and Islamism. Journal of Consumer Research, 39(4), 663-687.

Jacoby, J., \& Chestnut, R. W. (1978). Brand Loyalty: Measurement and Management. New York: John Wiley \& Sons Inc.

Jacoby, J., \& Kyner, D. B. (1973). Brand Loyalty Vs Repeat Purchasing Behavior. Journal of Marketing Research, 10(1), 1-9.

Karaşahin, H. (2008). Din Sosyolojisinde Dindarlığın Ölçülmesi Problemi Üzerine Bir Araştirma. Ankara Üniversitesi İlahiyat Fakültesi Dergisi, 49(1), 191-200.

Muhamad, N., \& Mizerski, D. (2013). The Effects of Following Islam in Decisions about Taboo Products. Psychology \& Marketing, 30(4), 357-371.

Kayıklık, H. (2006). Bireysel Dindarlığın Boyutlari ve İnanç-Davranış Etkileşimi. İslami Araştırmalar Dergisi, 19(3), 491-499.

Landrine, H., \& Klonoff, E. A. (1996). The Schedule of Racist Events: A Measure of Racial Discrimination and a Study of Its Negative Physical and Mental Health Consequences. Journal of Black Psychology, 22, 144-168.

Nosek, B. A., Smyth, F.L., Sriram, N., Lindner, N. M., Devos, T., Ayala, A., Bar-Anan, Y., Bergh, R., Cai, H., Gonsalkorale, K., Kesebir, S., Maliszewski, N., Neto, F., Olli, E., Park, J., Schnabel, K., Shiomura, K., Tulbure, B. T., Wiers, R. W., Somogyi, M., Akrami, N., Ekehammar, B., Vianello, M., Banaji, M. R., \& Greenwald, A. G. (2009). National Differences In Gender-Science Stereotypes Predict National Sex Differences In Science And Math Achievement. Proceedings of the National Academy of Sciences, 106, 10593-10597.

Odabasi, Y., \& Argan, M. (2009). Aspects of Underlying Ramadan Consumption Patterns in Turkey. Journal of International Consumer Marketing, 21, 203-218.

Patwardhan, A. M., Keith, M. E., \& Vitell, S. J. (2012). Religiosity, Attitude toward Business, And Ethical Beliefs: Hispanic Consumers in the United States. Journal of Business Ethics, 110(1), 61-70.

Rundle-Thiele, S., \& Mackay, M. M. (2001). Assessing the Performance of Brand Loyalty Measures. Journal of Service Marketing, 15(7), 529-546. 
Sandikci, O., \& Ger, G. (2010). Veiling in Style: How Does a Stigmatized Practice Become Fashionable? Journal of Consumer Research, 37(1), 15-36.

Sandikci, O., \& Rice, G. (2011). Handbook of Islamic Marketing. Glos: Edwar Elgar Publishing.

Şeker, N. (2011). İslâm Kültürü ve Değişim Bağlamında Sünnet Algısı. EKEV Akademi Dergisi, $47,175-194$.

Sirdeshmukh, D., Singh, J., \& Sabol, B. (2002). Consumer Trust, Value, and Loyalty in Relational Exchanges. Journal of Marketing, 66(1), 15-37.

Smart, N. (1984). The Religious Experience of Mankind. New York: Charles Scribner's Sons.

Stark, R., \& Glock, C. Y. (1978). Dimension of Religious Commitment. In Sociology of Religion (Ed. Robertson R) UK: Penguin Books, 253-261.

Swimberghe, K. R., Sharma, D., \& Flurry, L. W. (2011). Does A Consumer's Religion Really Matter in the Buyer-Seller Dyad? An Empirical Study Examining the Relationship between Consumer Religious Commitment, Christian Conservatism and the Ethical Judgment of a Seller's Controversial Business Decision. Journal of Business Ethics, 102, 581-598.

Tucker, W. T. (1964). The Development of Brand Loyalty. Journal of Marketing Research, 1(3), 32-35.

Uğurlu, S. B. (2009). Otomobil ve Benlik: Türk Edebiyatinda Araba Olgusu. Turkish Studies, $4(1), 1427-1462$.

Vitell, S. J. (2010). The Role of Religiosity in Business and Consumer Ethics: A Review of the Literature. Journal of Business Ethics, 90, 155-167.

Worthington, E. L. Jr., Wade, N. G., Hight, T. L., Ripley, J. S., McCullough, M. E., Berry, J. W., Schmitt, M. M., Berry, J. T., Bursley, K. H., \& O'Connor, L. (2003) The Religious Commitment Inventory-10: Development, Refinement, and Validation of A Brief Scale For Research and Counseling. Journal of Counseling Psychology, 50(1), 84-96.

Yoon, J. (1996). Conspicuous Conssumption and Social Status in Korea: An Assessment of Reciprocal Effects. Korea Journal of Population and Development, 25(2), 333-354. 